\title{
Anticancer activity of streptochlorin, a novel antineoplastic agent, in cholangiocarcinoma
}

\author{
This article was published in the following Dove Press journal: \\ Drug Design, Development and Therapy \\ 16 April 2015 \\ Number of times this article has been viewed
}

\section{Tae Won Kwak',* \\ Hee Jae Shin ${ }^{2, *}$ \\ Young-Il Jeong' \\ Myoung-Eun $\mathrm{Han}^{3}$ \\ Sae-Ock Oh ${ }^{3}$ \\ Hyun-Jung $\mathrm{Kim}^{4}$ \\ Do Hyung Kim ${ }^{5}$ \\ Dae Hwan Kang'}

'Biomedical Research Institute, Pusan National University Hospital, Busan, ${ }^{2}$ Marine Natural Products Chemistry Laboratory, Korea Institute of Ocean Science and Technology, Ansan, ${ }^{3}$ Department of Anatomy, School of Medicine, Pusan National University, Gyeongnam, ${ }^{4}$ Genewel Co Ltd. Gyeonggi-do, ${ }^{5}$ School of Medicine, Pusan National University, Yangsan, Gyeongnam, Republic of Korea

*These authors contributed equally to this work
Correspondence: Dae Hwan Kang Biomedical Research Institute and Department of Gastroenterology, Pusan National University Hospital, 179 Gudeok-ro, Seo-gu, Busan 602-739, Republic of Korea

Tel +825 53603870

Fax +825 53603879

Email sulsulpul@naver.com

\section{Young-II Jeong}

Biomedical Research Institute, Pusan National University Hospital, 179

Gudeok-ro, Seo-gu, Busan 602-739,

Republic of Korea

Tel +825 53603873

Fax +825 53603879

Email nanomed@naver.com
Background: The aim of this study is to investigate the anticancer activity of streptochlorin, a novel antineoplastic agent, in cholangiocarcinoma.

Methods: The anticancer activity of streptochlorin was evaluated in vitro in various cholangiocarcinoma cell lines for apoptosis, proliferation, invasiveness, and expression of various protein levels. A liver metastasis model was prepared by splenic injection of HuCC-T1 cholangiocarcinoma cells using a BALB/c nude mouse model to study the systemic antimetastatic efficacy of streptochlorin $5 \mathrm{mg} / \mathrm{kg}$ at 8 weeks. The antitumor efficacy of subcutaneously injected streptochlorin was also assessed using a solid tumor xenograft model of SNU478 cells for 22 days in the BALB/c nude mouse.

Results: Streptochlorin inhibited growth and secretion of vascular endothelial growth factor by cholangiocarcinoma cells in a dose-dependent manner and induced apoptosis in vitro. In addition, streptochlorin effectively inhibited invasion and migration of cholangiocarcinoma cells. Secretion of vascular endothelial growth factor and activity of matrix metalloproteinase- 9 in cholangiocarcinoma cells were also suppressed by treatment with streptochlorin. Streptochlorin effectively regulated metastasis of HuCC-T1 cells in a mouse model of liver metastasis. In a tumor xenograft study using SNU478 cells, streptochlorin significantly inhibited tumor growth without changes in body weight when compared with the control.

Conclusion: These results reveal that streptochlorin is a promising chemotherapeutic agent to the treatment of cholangiocarcinoma.

Keywords: streptochlorin, cholangiocarcinoma, chemotherapeutic agent, invasion, metastasis

\section{Introduction}

Cholangiocarcinoma (CC), which often arises from the epithelium of the biliary tract, is one of the most aggressive cancers, and patients with advanced CC normally have less than 2 years of median survivability. ${ }^{1-5}$ Most $\mathrm{CC}$ patients are diagnosed at an advanced stage due to difficulties in diagnosis ${ }^{2,4}$ and have a poor prognosis. Current clinical trials, such as surgical resection, endoscopic stent placement, chemotherapy, radiation therapy, and photodynamic therapy, can be mentioned as feasible treatment options. $^{6-13}$ Surgical resection can be considered as a curable treatment for early-stage tumors, but the majority of $\mathrm{CC}$ patients are initially diagnosed at an advanced stage where no curative options are presently available. ${ }^{6}$ Palliative treatment options, such as endoscopic stent placement, chemotherapy, radiation therapy, and photodynamic therapy, have also been used to treat CC patients, but are still questionable. ${ }^{6-8}$ In spite of low efficacy, chemotherapy remains the most reasonable of all the treatment options, but most conventional chemotherapeutic approaches, such as cisplatin, oxaliplatin, gemcitabine, and paclitaxel, consistently showed limited efficacy in CC patients. ${ }^{9-13}$ Further, although current standard chemotherapy based on platinum and gemcitabine can have 
positive clinical outcomes, the survival rate has not shown any significant improvement, ie, gemcitabine plus cisplatin has a survival benefit of less than 6 months when compared with single-agent treatment. ${ }^{10-13}$ Thus, novel chemotherapeutic options are required to inhibit progression of CC. ${ }^{14,15}$

Streptochlorin, a novel class of antineoplastic agents, has anticancer, antiangiogenic, and antiallergic effects. ${ }^{16-20}$ Previously, Shin et al reported on streptochlorin isolated from marine-derived Streptomyces sp. 04DH110 and its structure was defined. ${ }^{19}$ Specifically, streptochlorin inhibits activation of nuclear factor kappa $\mathrm{B}(\mathrm{NF \kappa B})$ and has anti-angiogenic/anti-invasive activity in cancer cells. ${ }^{16}$ Streptochlorin inhibited vascular endothelial growth factor (VEGF)-induced invasion and tube formation in human umbilical vein endothelial cells at very low concentrations, indicating that streptochlorin would be effective in decreasing the potential of cancer cells to metastasize. ${ }^{16}$ Streptochlorin also induced apoptosis of human leukemic U937 cells. ${ }^{18}$ It has a proapoptotic effect against U937 cells via activation of caspases and the mitochondria.

In this study, we investigated the anticancer efficacy of streptochlorin against various CC cell lines. Since CC cells have different physiological behavior compared to other systemic cancer cells, streptochlorin as an anticancer agent was evaluated with various carcinogenic behavior of $\mathrm{CC}$ cells such as proliferation, apoptosis, invasion, migration and metastasis.

\section{Materials and methods Chemicals}

Streptochlorin was obtained as previously reported. ${ }^{19}$ Roswell Park Memorial Institute (RPMI) 1640 medium, fetal bovine serum, and other components used for cell culture were purchased from Life Technologies (Grand Island, NY, USA). Fluorescein isothiocyanate-conjugated Annexin V and propidium iodide were purchased from BD Biosciences (Franklin Lakes, NJ, USA). All reagents used were extrapure grade.

\section{Cell culture}

HuCC-T1 (human intrahepatic cholangiocarcinoma) cell line was obtained from the Health Science Research Resources Bank (Osaka, Japan), and SNU478 (human ampulla of Vater carcinoma), SNU1196 (human extrahepatic cholangiocarcinoma), and SNU245 (human common bile duct carcinoma) cells from the Korean Cell Line Bank (Seoul, Korea). All CC cells were maintained in RPMI 1640 medium supplemented with $10 \%$ fetal bovine serum and $1 \%$ antibiotics.

\section{Trypan blue exclusion assay}

$\mathrm{CC}$ cells were seeded in 24-well plates at densities of $3 \times 10^{4}$ cells $/ \mathrm{mL}$ for inhibition of growth and $3 \times 10^{5}$ cells $/ \mathrm{mL}$ for anticancer activity, respectively. After incubation overnight, streptochlorin dissolved in dimethyl sulfoxide and diluted with culture medium was added to the $\mathrm{CC}$ cells and inhibition of cell growth was monitored for 24 hours. Anticancer activity was assessed with streptochlorin diluted in serum-free RPMI 1640 medium. The cells were harvested by trypsinization and resuspended. Trypan blue was then added for cell counting. Growth inhibition and cytotoxicity were evaluated by counting the number of cells using a Countess automated cell counter (Invitrogen, Carlsbad, CA, USA).

\section{Annexin V/propidium iodide binding assay}

First, $1 \times 10^{6}$ cells seeded in $100 \mathrm{~mm}$ dishes were treated with various concentrations of streptochlorin for 24 hours. The cells were harvested by trypsinization and then washed with phosphate-buffered saline (PBS). The cells were resuspended in $100 \mu \mathrm{L}$ of binding buffer (10 mM 4-(2-hydroxyethyl)-1piperazine ethanesulfonic acid [HEPES] pH 7.4, $150 \mathrm{M}$ $\left.\mathrm{NaCl}, 5 \mathrm{mM} \mathrm{KCl}, 1 \mathrm{mM} \mathrm{MgCl}, 1.8 \mathrm{mM} \mathrm{CaCl}_{2}\right)$. Fluorescein isothiocyanate-Annexin $\mathrm{V}(1 \mu \mathrm{g} / \mathrm{mL})$ was added to stain the apoptotic cells following incubation for 30 minutes. Ten minutes before termination, propidium iodide $10 \mu \mathrm{g} / \mathrm{mL}$ was added to stain the necrotic cells. Apoptotic and necrotic cells were then detected using an FACScan flow cytometer with a $15 \mathrm{~mW}$ argon laser and excitation at $488 \mathrm{~nm}$ (Becton, Dickinson and Company, Franklin Lakes, NJ, USA) according to the manufacturer's instructions.

\section{Protein lysates and Western blot analysis}

Western blot analysis was performed as described previously. ${ }^{21}$ Cells seeded in $100 \mathrm{~mm}$ culture dishes were treated with streptochlorin for 24 hours. Cells were detached by trypsinization, washed with PBS, and harvested by centrifugation. The cell pellets were lysed with lysis buffer (50 mM Tris, $150 \mathrm{mM}$ $\mathrm{NaCl}, 1 \%$ NP-40, 0.5\% deoxycholic acid, $0.1 \%$ sodium dodecyl sulfate, [SDS]) along with phenylmethylsulfonyl fluoride and a protease inhibitor cocktail (Roche Diagnostics, Indianapolis, IN, USA). The lysed cell suspension was centrifuged at $14,000 \times g$ for 30 minutes at $4^{\circ} \mathrm{C}$, and the cell lysates were collected. The protein concentration was determined using a bicinchoninic acid protein assay kit (Pierce, Rockford, IL, USA). Western blotting procedures were as follows: $50 \mu \mathrm{g}$ of protein was introduced into SDS polyacrylamide gel electrophoresis (SDS-PAGE) and then transferred to a polyvinylidene difluoride membrane. Proteins in the membrane 
were blocked with 5\% skim milk in TBS-T and probed with an appropriate primary antibody followed by a secondary horseradish peroxidase-conjugated antibody. Proteins were detected by chemiluminescence (Davinch-k, Seoul, Korea). After stripping the blotted antibody, the membranes were probed again with anti-glyceraldehyde-3-phosphate dehydrogenase primary antibody and the appropriate secondary antibody. Protein bands were analyzed for quantification.

\section{Measurement of active caspase- 3 levels}

SNU478 and HuCC-T1 cells $\left(1 \times 10^{6}\right)$ were seeded in $100 \mathrm{~mm}$ disks and treated with streptochlorin for 24 hours in order to detect active caspase-3, a marker for apoptosis. After treatment, the cells were washed in ice-cold PBS and lysed in lysis buffer. A caspase-3 (active) human enzyme-linked immunosorbent assay kit (Invitrogen Corporation, Camarillo, CA, USA) was used according to the protocols described in the manufacturer's instructions. For determination of active caspase-3, $100 \mu \mathrm{L}$ of cell lysate was incubated in microplate wells at room temperature for 2 hours. The samples were aspirated and washed four times with washing buffer and incubated with $100 \mu \mathrm{L}$ of detection antibody (anti-active caspase-3) for 1 hour at room temperature. After removal of the antibody solution, the wells were washed again and incubated with $100 \mu \mathrm{L}$ of horseradish peroxidase anti-rabbit antibody for 30 minutes at room temperature. After aspiration of the anti-rabbit antibody, a blue color was developed by adding $100 \mu \mathrm{L}$ of stabilized chromogen solution for 20 minutes at room temperature. The reaction was stopped by addition of $100 \mu \mathrm{L}$ of stop solution. The absorbance of each well was read at $450 \mathrm{~nm}$ using a microplate reader. The results were representative of three independent experiments.

\section{Gelatin zymography}

First, $1 \times 10^{6}$ cells seeded in six-well plates were treated with streptochlorin in serum-free medium for 24 hours. The medium was then harvested and the protein content was measured using the bicinchoninic acid protein assay kit. The matrix metalloproteinase (MMP) activity in the conditioned medium was evaluated by gelatin zymography (SDS-PAGE containing 10\% gelatin). An equal amount of protein in conditioned medium was mixed with Lammeli buffer under non-reducing conditions and separated. To remove the SDS, the gels were soaked in buffer $(2.5 \%$ Triton $\mathrm{X}-100$ in PBS) three times for 30 minutes and then incubated for 24 hours at $37^{\circ} \mathrm{C}$. The gels were then stained with $0.1 \%$ Coomassie Brilliant Blue R-250. Quantitative results of the assays were obtained.

\section{Wound healing assay}

A wound healing assay was performed as reported previously. ${ }^{21}$ First, $5 \times 10^{5}$ cells in RPMI 1640 supplemented with $10 \%$ fetal bovine serum were seeded into a wound healing assay kit containing ibidi Culture-Inserts (ibidi GmbH, Planegg/Martinsried, Germany). These were then cultured overnight, after which the ibidi CultureInserts were removed. The cells were then treated with streptochlorin for 24 hours. The wound healing and migrated cell zones were observed using light microscopy. To avoid growth-dependent migration of cells, serum-free medium was used.

\section{Invasion assay}

The invasion assay was performed as reported previously. ${ }^{21}$ To measure the anti-invasive effect of streptochlorin, the upper chambers in 24-well plates were used. The upper chamber was coated with $50 \mu \mathrm{L}$ of Matrigel $^{\circledR}(1 \mathrm{mg} / \mathrm{mL}$; BD Biosciences, San Jose, CA, USA), and $2 \times 10^{4}$ cells in $100 \mu \mathrm{L}$ of serum-free medium were then seeded on the upper parts of the chamber. These were then placed into the 24 -well plate. Next, $600 \mu \mathrm{L}$ of RPMI 1640 medium containing 10\% fetal bovine serum with or without streptochlorin was added to the lower chamber. After incubation for 24 hours, cells invading the lower surface of the membrane were fixed with methanol and stained with hematoxylin and eosin. The number of cells invading various areas of the lower membrane surface was counted using a computerized video image analyzing system. Each assay was performed in triplicate and the results are expressed as the mean \pm standard deviation.

\section{Murine model of liver metastasis}

To evaluate the anti-metastatic activity of streptochlorin, HuCC-T1 cells $\left(1 \times 10^{6} / 0.1 \mathrm{~mL}\right)$ were injected to the spleen of nude mice using 27 gauge needle (Control, PBS-treated group; Streptochlorin, streptochlorin-treated group; $n=5$ per group). For injection, streptochlorin was dissolved in $1 \mathrm{~mL}$ of a mixture of Cremophor ${ }^{\circledR}$ EL/ethanol $(1 / 1, v / v)$ and diluted ten times. Two weeks later, $100 \mu \mathrm{L}$ of streptochlorin solution $(5 \mathrm{mg} / \mathrm{kg})$ was injected intravenously via the tail vein into each mouse. Six weeks after injection of the drug, all the mice were sacrificed and their livers were isolated to observe the metastatic behavior of HuCC-T1 cells.

\section{Tumor xenograft study}

Mice were also used to investigate the antitumor activity of streptochlorin. SNU478 cells $\left(1 \times 10^{7} / 0.1 \mathrm{~mL}\right)$ were subcutaneously injected into the backs of male nude mice (BALB/c 
nude mouse, 5 weeks old and 20-25 g in weight, Orient, Seongnam, South Korea). When the diameter of the tumor on the back of each mouse reached approximately $5 \mathrm{~mm}$ (approximately 3 weeks later), the mice were divided into three groups, ie, control, vehicle, and streptochlorin + vehicle. Each group consisted of four or five mice. For the control group, PBS ( $\mathrm{pH} 7.4,0.01 \mathrm{M}$ ) was administered subcutaneously. For the streptochlorin + vehicle group, streptochlorin $5 \mathrm{mg} / \mathrm{kg}$ was suspended in $100 \mu \mathrm{L}$ of thermosensitive gel (Guardix-SG, Genewel Co, Seongnam, Korea) and then subcutaneously injected beside solid tumor. For the vehicle group, thermosensitive gel was injected subcutaneously beside solid matter. The total volume injected was $100 \mu \mathrm{L}$. All animals were monitored daily and had free access to feed and sterilized water. Tumor volume and body weight changes were measured at 3-4-day intervals for 22 days. Tumor volume was calculated using the formula $V=\left(a \times[b]^{2}\right) / 2$, where $a$ is the largest diameter and $b$ is the smallest diameter.

\section{Immunohistochemistry}

Tumors were enucleated 22 days later from drug injection. The solid tumor was fixed in 4\% formaldehyde and paraffin-embedded. The fixed tumor mass was then sliced for hematoxylin/eosin staining or immunohistochemical staining, ie, slices of the solid tumor sample were stained with various antibodies such as proliferating cell nuclear antigen (PCNA), cyclin D1, mut-p53, wt-p53, MDM-2, p21, NFкB, Nrf2, Notch 1, MMP-2, MMP-9, VEGF, Bad, Bax, Bcl-2, and cytochrome c antibody (dilution 1:100). Staining was performed using an Envision kit (Life Technologies) according to the manufacturer's protocol.

\section{Animal study}

This study was carried out in strict accordance with the recommendations in the Guide for the Care and Use of Laboratory Animals of the National Institutes of Health. The Pusan National University Institutional Animal Care and Use Committee approved the experimental procedures.

\section{Quantification of image intensity}

Quantification of intensities and protein levels was calculated using ImageJ version $1.42 \mathrm{q}$ software (National Institutes of Health, Bethesda, MD, USA).

\section{Statistical analysis}

Statistical comparisons of the data between control and treated cells or animals were performed using the Student's $t$-test. $P<0.05$ was considered to be statistically significant.

\section{Results}

\section{Streptochlorin inhibits proliferation and suppresses viability of CC cells}

The growth inhibition and anticancer activity of CC cells were studied in vitro as shown in Figure 1. Growth inhibition was used to investigate the effect of streptochlorin on proliferation of $\mathrm{CC}$ cells in the presence of serum protein. As shown in Figure 1A, streptochlorin induced dose-dependent inhibition of CC cell growth up to $200 \mu \mathrm{M}$. Further, anticancer activity was tested to assess the extent of cell death caused by streptochlorin. Among the various types of CC cells, growth of SNU1196 cells was inhibited by less than $20 \%$ at streptochlorin concentrations higher than $50 \mu \mathrm{M}$ and growth inhibition of other cell lines was almost less than 25\% at $200 \mu \mathrm{M}$. For anticancer activity, cells were treated with streptochlorin in the absence of serum protein to exclude any growth-associated effect. As shown in Figure 1B, viability of the CC cell lines was gradually decreased by an increase in streptochlorin concentration (Figure 1B). In particular, the viability of HuCC-T1 and SNU478 cells was decreased in a linear manner according to the increase in streptochlorin. However, the viability of SNU245 cells was higher than $80 \%$ at $100 \mu \mathrm{M}$, and SNU1196 showed more than $30 \%$ viability at $200 \mu \mathrm{M}$. We then selected SNU478 and HuCC-T1 cells for further study. As shown in Figure 1C, streptochlorin effectively inhibited the viability of $\mathrm{CC}$ cells. The $\mathrm{IC}_{50}$ value is given in Table 1, indicating that streptochlorin has potential as an anticancer agent against human CC cells.

\section{Streptochlorin inhibits VEGF secretion, migration, and invasion of $\mathrm{CC}$ cells}

Figure S1 shows the effect of streptochlorin on VEGF secretion from SNU478 cells. VEGF protein secreted from cells was significantly decreased when they were treated with $100 \mu \mathrm{M}$ of streptochlorin, even though intracellular VEGF was slightly increased. Figure 2 shows the migration, MMP-9 activity, and invasive behavior of CC cells. The effect of streptochlorin on migration of $\mathrm{CC}$ cells was tested using the wound healing assay method. As shown in Figure 2A, migration of HuCC-T1 cells was gradually inhibited with increasing streptochlorin concentration. Further, streptochlorin effectively inhibited migration of SNU478 cells at lower concentrations. Since MMP-9 has a crucial role in degradation of the basement membrane and invasion of tumor cells, its activity in the supernatant of cell culture is regarded as an indicator of the capacity of tumor cells for invasion. As shown in Figure 2B, MMP-9 

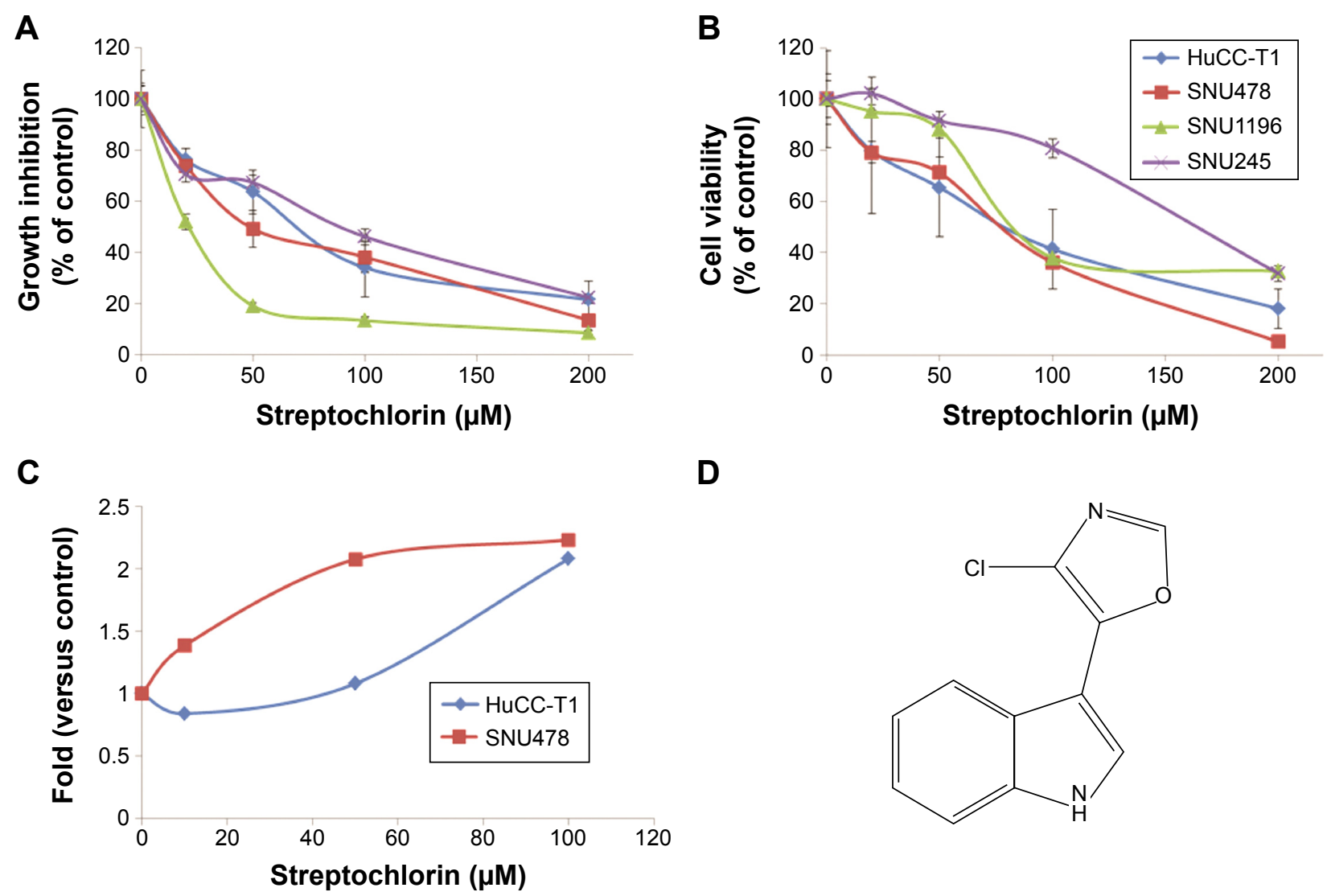

D

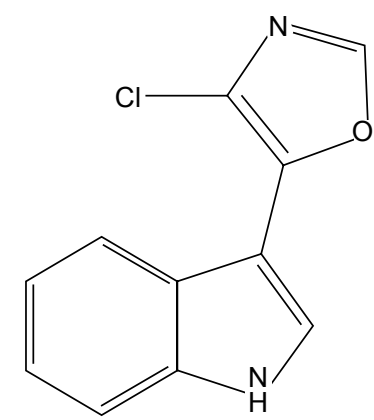

Figure I Anticancer activity of streptochlorin in CC cells.

Notes: (A) Growth inhibition of CC cells. (B) Anticancer activity test: $3 \times 10^{4}$ and $3 \times 10^{5} \mathrm{CC}$ cells were seeded in 24-well plates for growth inhibition and an anticancer activity test, respectively. (C) Analysis of apoptosis using Annexin V. (D) Chemical structure of streptochlorin.

Abbreviation: $\mathrm{CC}$, cholangiocarcinoma.

activity decreased significantly in a dose-dependent manner. Specifically, MMP-9 activity after treatment with streptochlorin $100 \mu \mathrm{M}$ was almost half that in the control group. The invasiveness of HuCC-T1 and SNU478 cells was studied using the Matrigel ${ }^{\circledR}$ invasion assay as shown in Figure 2C. Invasion of HuCC-T1 cells and SNU478 cells decreased gradually in a dose-dependent manner. When treated with streptochlorin $100 \mu \mathrm{M}$, the invasiveness of HuCC-T1 and SNU478 cells decreased by $62.6 \%$ and $57.3 \%$, respectively, versus the control. As shown in Figure 2D, Notch 1 expression was also decreased by half on treatment with streptochlorin. These results suggest that streptochlorin effectively inhibits angiogenesis, migration, and invasion of $\mathrm{CC}$ cells.

Table I IC of $_{0}$ streptochlorin against various cholangiocarcinoma cell lines

\begin{tabular}{ll}
\hline & IC $_{50}(\mu \mathrm{M})$ \\
\hline HuCC-TI & 67.50 \\
SNU478 & 52.96 \\
SNUII96 & 20.84 \\
SNU245 & 60.36 \\
\hline
\end{tabular}

Further, regulation of the motility of cancer cells by streptochlorin suggests that streptochlorin regulates metastasis of cancer cells in vivo. To examine this possibility, we injected HuCC-T1 cells into the spleens of nude mice and then observed metastasis in the liver, as shown in Figure 3. The extent and size of metastatic region of HuCC-T1 cells in liver was significantly decreased by treatment of streptochlorin, while the control group showed extensive metastasis of HuCC-T1 cells (Figure 3).

\section{Streptochlorin-induced apoptotic signals}

Figure 4 shows that the expression of various apoptotic signals from HuCC-T1 and SNU478 cells was changed after treatment with streptochlorin. As shown in Figure 4A, expression of mutant $\mathrm{p} 53$ decreased in HuCC-T1 and SNU478 cells in response to treatment with streptochlorin $100 \mu \mathrm{M}$, while expression of wild-type p53 was slightly increased. Active caspase-3 was also significantly increased by streptochlorin $100 \mu \mathrm{M}$ in SNU478 cells, while HuCC-T1 cells showed only small changes (Figure 4B). Further, cleaved PARP was also increased in HuCC-T1 and SNU478 cells treated 
A

Concentration of streptochlorin $(\mu \mathrm{M})$

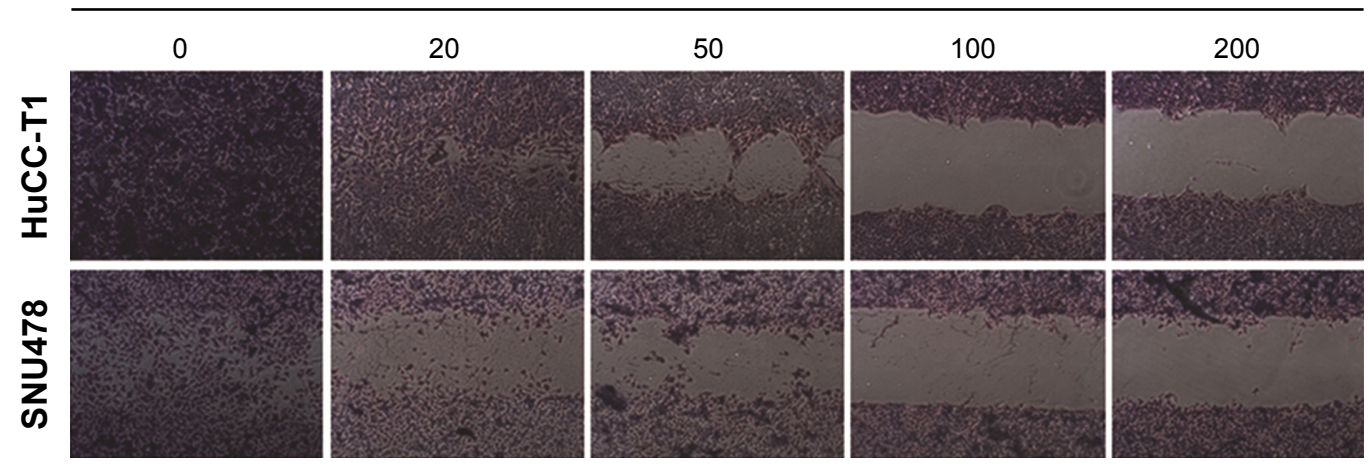

B

Concentration of streptochlorin $(\mu \mathrm{M})$

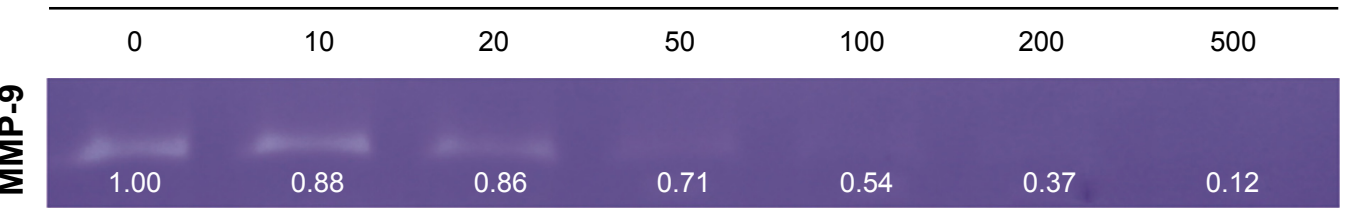

C Concentration of streptochlorin ( $\mu \mathrm{M})$

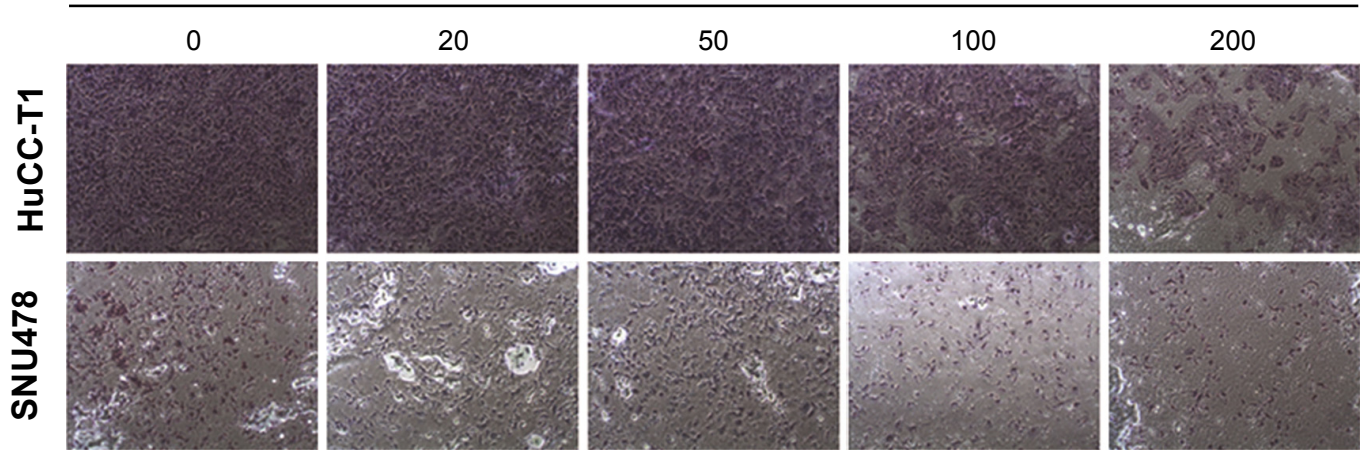

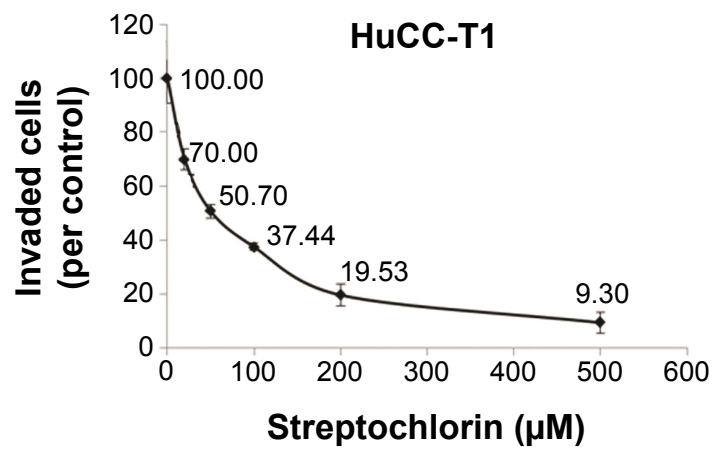

D

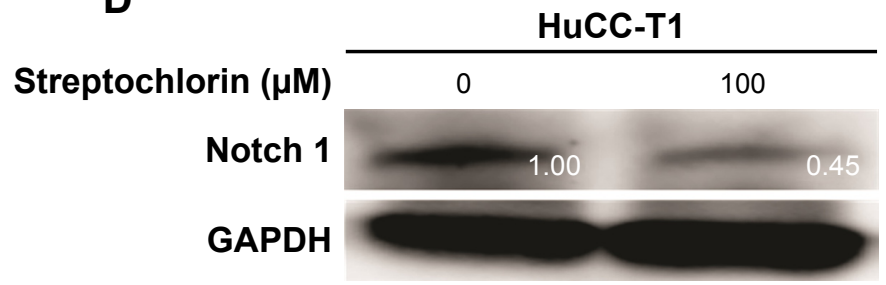

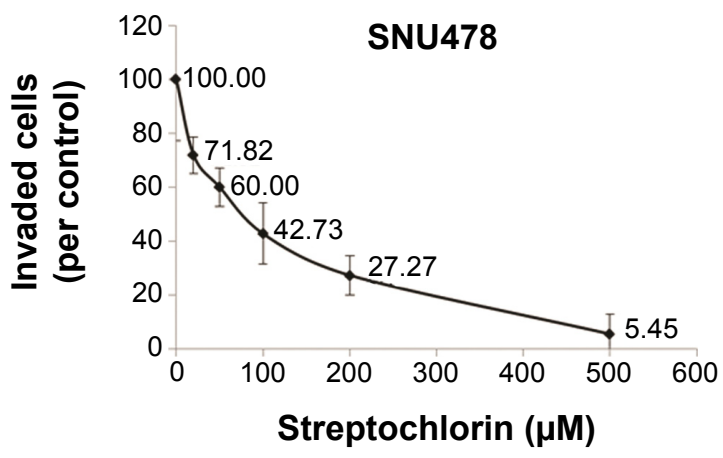

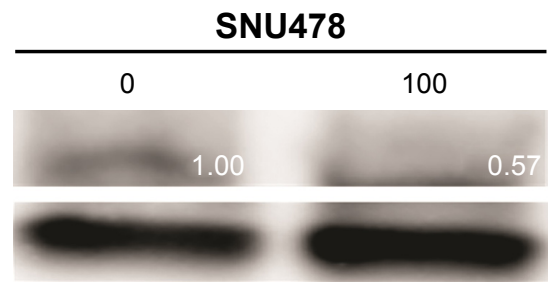

Figure 2 Effect of streptochlorin on HuCC-TI cells and SNU478 cells.

Notes: (A) Migration test using the wound healing assay. (B) Gelatin zymography of HuCC-TI cells. (C) Invasion test was performed using Matrigel ${ }^{\circledR}$. (D) Notch I expression. Abbreviation: MMP, matrix metalloproteinase. 


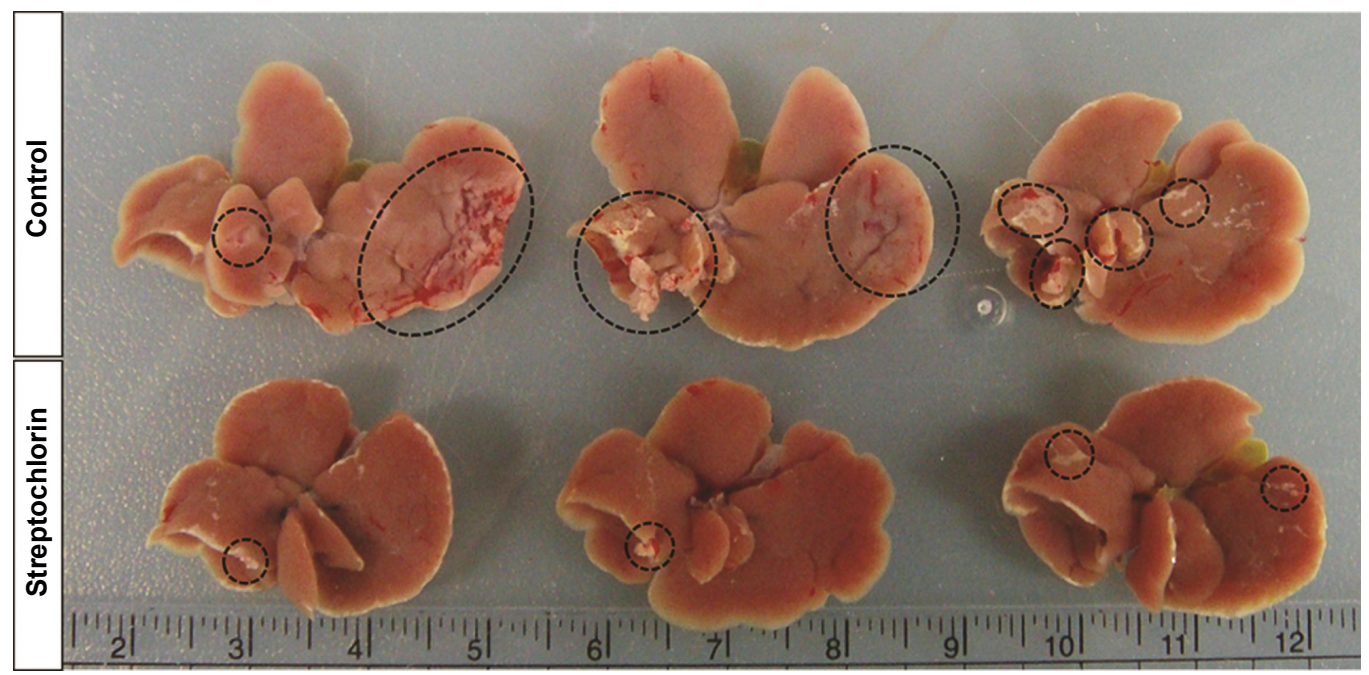

Figure 3 Antimetastatic effect of streptochlorin.

Notes: To create a liver metastasis model, HuCC-TI cells $\left(I \times 10^{6}\right.$ cell/mouse) were injected into the spleens of nude mice. Two weeks later, phosphate-buffered saline or streptochlorin $5 \mathrm{mg} / \mathrm{kg}$ was injected via the tail vein of the mouse. After 6 weeks of treatment, mice were sacrificed and the livers were taken to observe the metastatic potential of HuCC-TI cells. Dotted circle showed the metastatic region of HuCC-TI cells in liver.

A

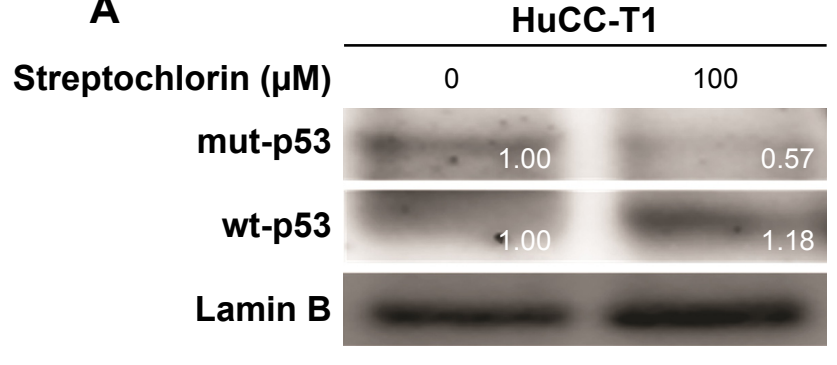

\section{SNU478}

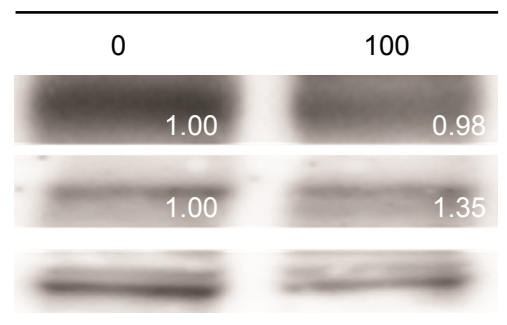

B

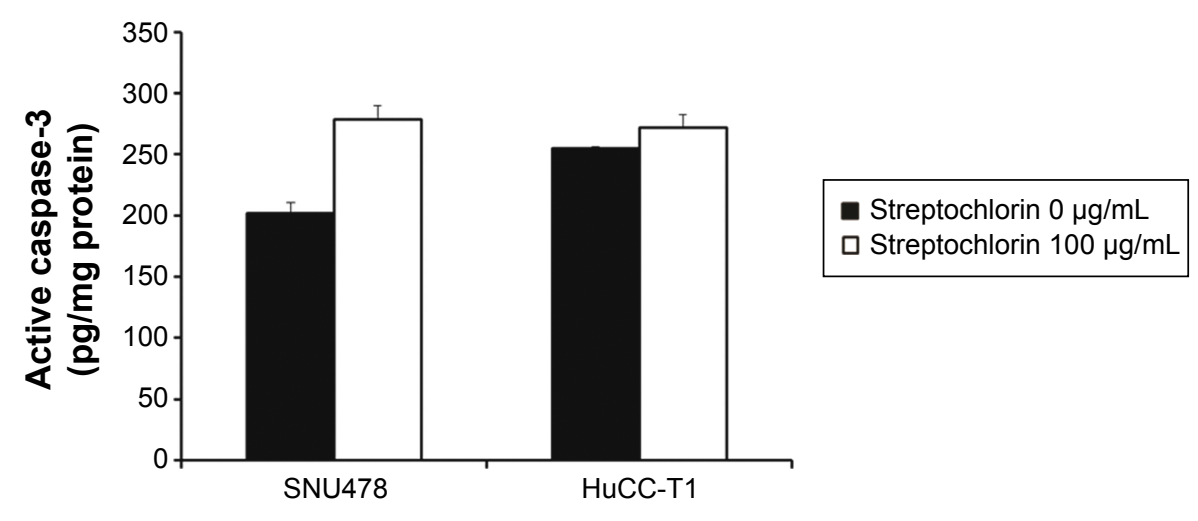

C

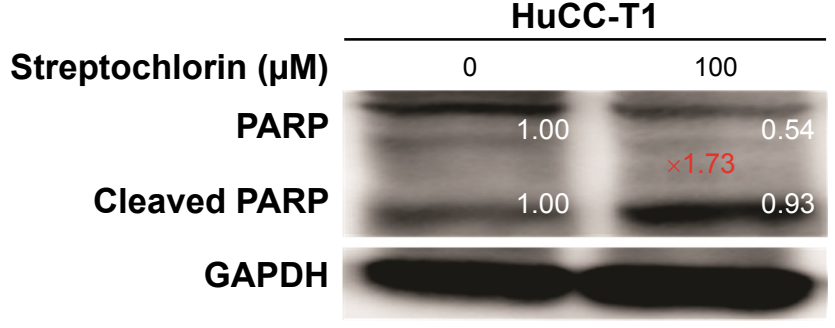

SNU478

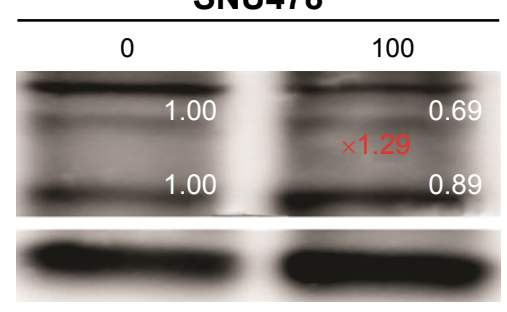

Figure 4 Various apoptotic signals of HuCC-TI and SNU478 cells on treatment with streptochlorin.

Notes: (A) Wild-type and mutant p53, (B) caspase-3 activity, and (C) PARP expression. Cleaved PARP versus PARP was increased I.73 fold at HuCC-TI cells and I.29 fold at SNU478 cells, respectively.

Abbreviations: mut-p53, mutant p53; wt-p53, wild-type p53; PARP, poly ADP ribose polymerase. 
with streptochlorin $100 \mu \mathrm{M}$ as shown in Figure 4C. These results indicate clearly that streptochlorin induces apoptosis of CC cells in vitro.

\section{In vivo animal tumor xenograft study}

Figure 5A shows the changes in tumor volume. The size of solid tumor of control or vehicle treatment was rapidly increased. However, tumor volume growth was significantly inhibited by streptochlorin. Specifically, tumor volume in the streptochlorin-treated group was 6.6 times and 5.4 times smaller than that in the control and vehicle groups, respectively. Changes in body weight were not significantly different between the control, vehicle, and streptochlorin groups (Figure 5B), indicating that streptochlorin is not significantly cytotoxic to mice. Further, apoptotic signaling, such as mutant $\mathrm{p} 53$, was significantly decreased by treatment with streptochlorin (Figure S2). In particular, mutant p53 expression was very similar in the control and vehicle groups, whereas the streptochlorin + vehicle group showed a significant decrease in mutant $\mathrm{p} 53$ expression. Expression of wild-type p53 and MDM2 was
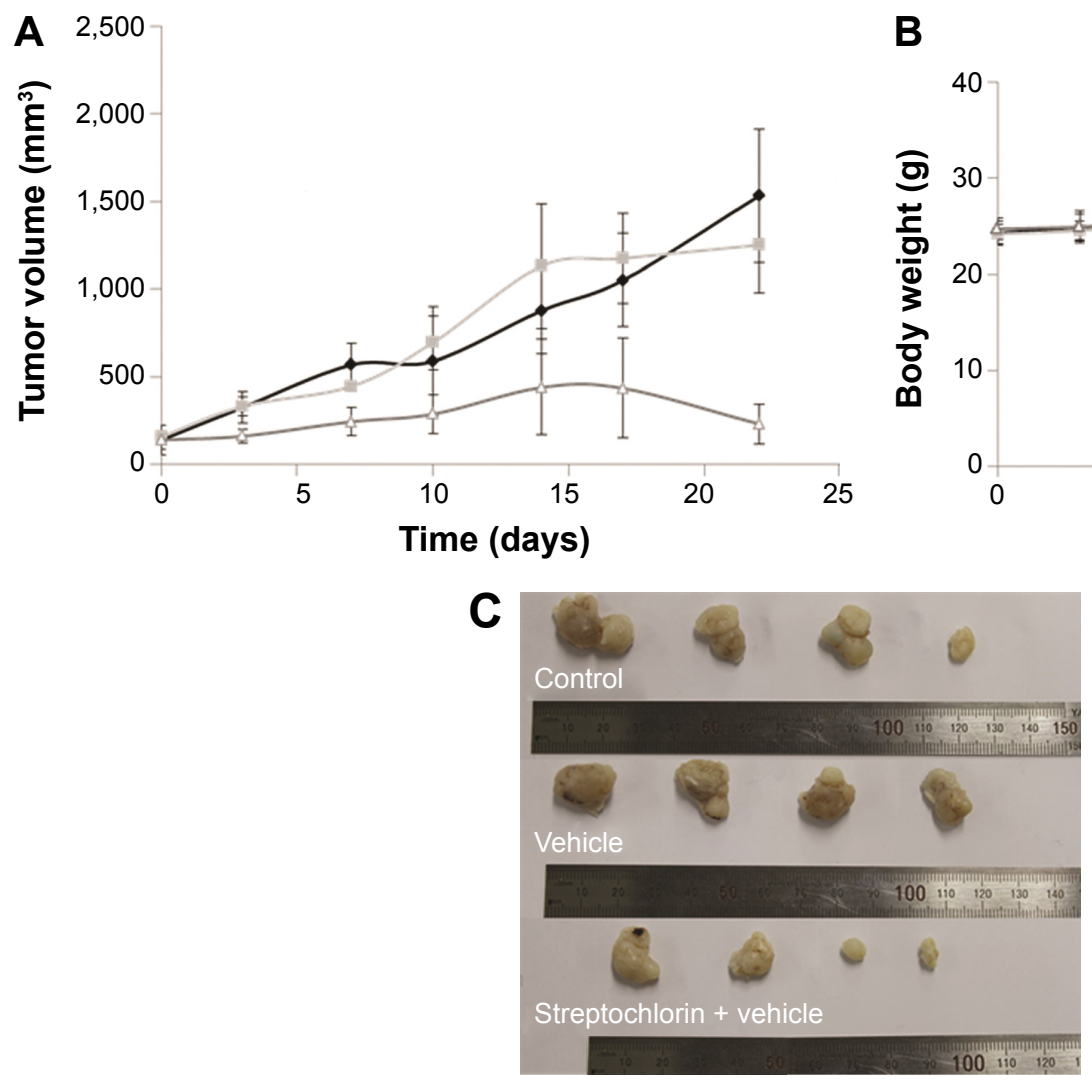

Figure 5 Antitumor activity of streptochlorin $5 \mathrm{mg} / \mathrm{kg}$ against SNU478 cells.

Notes: (A) Tumor volume and (B) body weight. Streptochlorin was administered subcutaneously when the tumor diameter reached approximately $5 \mathrm{~mm}$. Streptochlorin was suspended in thermosensitive gels (Guardix-SG, Genewel Co, Seongnam, Korea) and subcutaneously injected (5 mg/kg). (C) Body weight and tumor volume were measured twice weekly.

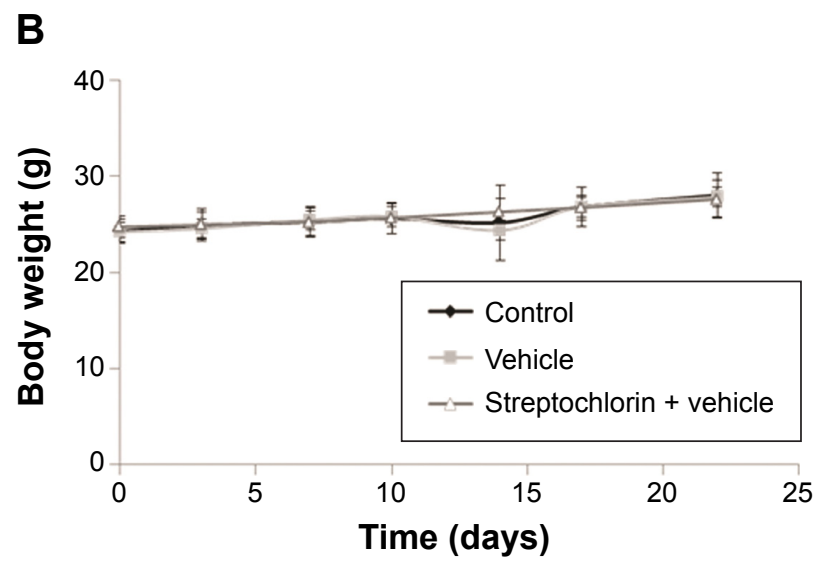

not significantly different between the treatment groups. Cell cycle-related proteins, such as cyclin D1, were significantly decreased, along with proliferation-related proteins, such as PCNA (Figure S2). Streptochlorin also decreased tumor metastasis and angiogenesis-related proteins, such as NFkB, Notch 1, MMP-2, MMP-9, and VEGF (Figure S3). Further, streptochlorin increased apoptosis-related signals, such as Bad, Bax, and cytochrome C, and decreased Bcl-2 (Figure S4). These results indicate that streptochlorin has promising anticancer activity against human $\mathrm{CC}$.

\section{Discussion}

$\mathrm{CC}$ is an aggressive disease with a low response to chemotherapeutic approaches. ${ }^{1,2,4,5,22,23}$ Most chemotherapeutic agents used to treat $\mathrm{CC}$, such as gemcitabine, capecitabine, cisplatin, irinotecan, paclitaxel, erlotinib, lapatinib, and 5-fluorouracil, as well as their combinations, achieve only short overall survival of less than 14 months. ${ }^{23}$ Despite of low anticancer efficacy, systemic side effects of conventional anticancer agents such as neurotoxicity or nephrotoxicity are frequently reported. ${ }^{24-27}$ 
Cancer cells, which became drug-resistant properties against these chemotherapeutic agents, is known to acquire invasion or metastatic properties. ${ }^{28}$ Palliative options such as photodynamic therapy, radiation therapy, and stent placement have also been investigated in attempts to prolong patient survival, but none have been successful. ${ }^{6-8}$ Since CC has different physiological/morphological features compared to other systemic cancers, most of the traditional chemotherapeutic agents has been showed low anticancer efficacy for CC in clinical applications because those are only concentrated in proliferation inhibition of cancer cells. ${ }^{22}$ Previously, we reported that vorinostat/epigallocatechin-3-gallate combinations have a synergistic effect not only with regard to inhibition of proliferation of cancer cells but also inhibition of invasion, migration, and angiogenesis of CC cells in vitro. ${ }^{21}$ Lee et al reported that addition of erlotinib to chemotherapy for advanced biliary tract cancer significantly prolonged median progression-free survival when compared with standard chemotherapy using gemcitabine and platinum. ${ }^{29}$ Targeted therapy using various molecular targeted agents, such as sorafenib, sunitinib, erlotinib, bevacizumab, and their combinations, clearly showed benefit in the clinic, but no practical survivability benefit for patients, with overall survival being generally less than 1 year. ${ }^{9}$ We have also previously reported that sorafenib has anticancer activity against HuCC-T1 cells and effectively inhibited tumor growth in an animal study. ${ }^{30}$ In light of these observations, we are attempting to find new chemotherapeutic agents for $\mathrm{CC}$.

Streptochlorin is a newly discovered antineoplastic agent derived from a marine organism. ${ }^{19}$ Streptochlorin inhibited proliferation of CC cells in a dose-dependent manner (Figure 1A) and suppressed viability of CC cells (Figure 1B). Only HuCC-T1 and SNU478 cells were selected for further study since SNU1196 and SNU245 showed a very slow proliferation rate and a minimal migration or invasion rate in the wound healing/invasion assay (data not shown). Mutant p53 genes are known to accelerate carcinogenesis and transformation of cells while wild-type p53 is associated with cell reapir. ${ }^{31}$ Mutant 553 was clearly suppressed by treatment with streptochlorin in vitro (Figure 4) and in vivo (Figure S2B), indicating that streptochlorin is effective in regulation of p53 gene expression. Further, streptochlorin is known to inhibit activation of NFKB and angiogenesis, and to induce apoptosis of cancer cells. ${ }^{16,18-20}$ Choi et al reported that streptochlorin inhibited angiogenesis in fibrosarcoma cells, ${ }^{16}$ and we also observed that streptochlorin effectively inhibited VEGF secretion in an in vitro model (Figure S1) and NFKB activation in an in vivo model (Figure S3). Because NFKB regulates angiogenesis-related genes and metastasis-related proteins, its expression is also related to VEGF and Notch 1. Suppression of these genes or proteins is thus related to inhibition of angiogenesis and tumor metastasis. As shown in Figure S3B, expression of NFאB, VEGF, and Notch 1 was evidently decreased on treatment with streptochlorin, indicating that streptochlorin also has antiangiogenic and antimetastatic activity. Further, inhibition of invasion/ migration potential must be endowed beneficial effect for chemotherapy since the invasion and migration are common paths for $\mathrm{CC}$ and highly correlated with postoperative recurrence and progression. ${ }^{32,33}$ In particular, we demonstrated that streptochlorin effectively inhibited the potential of CC cells to invade (Figure 2C) and migrate (Figure 3 ). The incidence ratio of perineural invasion of resected patients is known to higher than $80 \%$ and invasive capacity of CC cells has serious correlation with a poor 5-year survivability. ${ }^{34}$ The expression of invasion and migration factor of CC cells, such as MMP-2 and MMP-9, was clearly decreased in vitro and in vivo (see Figures 2B and S3B). Notch 1, which is also responsible for the migratory and invasive capacity of cancer cells, ${ }^{35}$ was effectively inhibited in vitro (Figure 2D) and in vivo (Figure S3A). Streptochlorin induced apoptosis and then death of various $\mathrm{CC}$ cell lines in vitro, as shown in Figures 1 and 4. We observed that streptochlorin effectively induced apoptotic signals, such as active caspase-3 and cleaved PARP, as shown in Figures 4, S2, and S4. Park et al reported that streptochlorin induced apoptosis of human leukemic U937 cells in vitro. ${ }^{18} \mathrm{We}$ observed that streptochlorin significantly inhibited growth of SNU478bearing tumors in our animal tumor xenograft study with no significant toxicity (Figure 5), ie, tumor volume growth was inhibited effectively by streptochlorin, with no effect on body weight. Immunohistochemical analysis showed that expression of cell cycle-related proteins, such as cyclin D1 and $\mathrm{p} 21$, was significantly increased when SNU478-bearing mice were treated with streptochlorin (Figure S2A). Mutant p53, MDM2, and PCNA were also decreased in the solid tumor model (Figure S2B). Further, streptochlorin increased apoptosis signaling, which was correlated with downregulation of antiapoptotic Bcl-2 expression, upregulation of proapoptotic Bax, Bad, and cytochrome $\mathrm{c}$, and activation of caspase-3, as shown in Figures 4 and S2-S4. These results clearly demonstrate that streptochlorin inhibits growth of solid tumors and induces apoptosis of tumor cells.

Streptochlorin was also tested using HEK293 cells to investigate intrinsic toxicity against normal cells (Figure S5). Streptochlorin was minimally cytotoxic and had a minimal 
growth inhibition effect on HEK293 cells, ie, more than $80 \%$ of HEK293 cells were viable after exposure to streptochlorin $200 \mu \mathrm{M}$. These results indicate that streptochlorin has cancer specific cytotoxicity, and can be considered as a promising candidate for inhibition of $\mathrm{CC}$ cells.

In conclusion, we investigated the anticancer potential of streptochlorin using various CC cell lines. Streptochlorin effectively inhibited growth of $\mathrm{CC}$ cells and induced apoptosis. It also inhibited VEGF secretion from CC cells, along with their invasion and migration potential and MMP activity. Furthermore, streptochlorin significantly inhibited tumor growth in an animal tumor xenograft study. From these results, we suggest that streptochlorin is a promising chemotherapeutic agent to the treatment of CC.

\section{Acknowledgments}

This study was supported by a grant of the Korean Health Technology R\&D Project, Ministry of Health \& Welfare, Republic of Korea (Project No. HI14C2220). This study was also supported in part by the Korea Institute of Ocean Science and Technology (PE99273 to HJS).

\section{Disclosure}

The authors report no conflicts of interest in this work.

\section{References}

1. Rizvi S, Gores GJ. Pathogenesis, diagnosis, and management of cholangiocarcinoma. Gastroenterology. 2013;145:1215-1229.

2. Sandhu DS, Roberts LR. Diagnosis and management of cholangiocarcinoma. Curr Gastroenterol Rep. 2008;10:43-52.

3. Welzel TM, McGlynn KA, Hsing AW, et al. Impact of classification of hilar cholangiocarcinomas (Klatskin tumors) on the incidence of intra- and extrahepatic cholangiocarcinoma in the United States. J Natl Cancer Inst. 2006;98:873-875.

4. Reddy SB, Patel T. Current approaches to the diagnosis and treatment of cholangiocarcinoma. Curr Gastroenterol Rep. 2006;8:30-37.

5. Singh $P$, Patel T. Advances in the diagnosis, evaluation and management of cholangiocarcinoma. Curr Opin Gastroenterol. 2006;22:294-299.

6. Mosconi S, Beretta GD, Labianca R, et al. Cholangiocarcinoma. Crit Rev Oncol Hematol. 2009;69:259-270.

7. Blechacz B, Gores GJ. Cholangiocarcinoma: advances in pathogenesis, diagnosis, and treatment. Hepatology. 2008;48:308-321.

8. Sirica AE. Cholangiocarcinoma: molecular targeting strategies for chemoprevention and therapy. Hepatology. 2005;41:5-15.

9. Noel MS, Hezel AF. New and emerging treatment options for biliary tract cancer. Onco Targets Ther. 2013;6:1545-1552.

10. Lee J, Kim TY, Lee MA; for the Korean Cancer Study Group. Phase II trial of gemcitabine combined with cisplatin in patients with inoperable biliary tract carcinomas. Cancer Chemother Pharmacol. 2008;61: 47-52.

11. Valle J, Wasan H, Palmer DH; for ABC-02 Trial Investigators. Cisplatin plus gemcitabine versus gemcitabine for biliary tract cancer. $N$ Engl $J$ Med. 2010;362:1273-1281.

12. Weigt J, Malfertheiner P. Cisplatin plus gemcitabine versus gemcitabine for biliary tract cancer. Expert Rev Gastroenterol Hepatol. 2010;4: 395-397.
13. Yang R, Wang B, Chen YJ, et al. Efficacy of gemcitabine plus platinum agents for biliary tract cancers: a meta-analysis. Anticancer Drugs. 2013; 24:871-877.

14. Faris JE, Zhu AX. Targeted therapy for biliary tract cancers. J Hepatobiliary Pancreat Sci. 2012;19:326-336.

15. Thomas MB. Systemic and targeted therapy for biliary tract tumors and primary liver tumors. Surg Oncol Clin N Am. 2014;23:369-381.

16. Choi IK, Shin HJ, Lee HS, et al. Streptochlorin, a marine natural product, inhibits NF-kappaB activation and suppresses angiogenesis in vitro. J Microbiol Biotechnol. 2007;17:1338-1343.

17. Lee SH, Shin HJ, Kim DY, et al. Streptochlorin suppresses allergic dermatitis and mast cell activation via regulation of Lyn/Fyn and Syk signaling pathways in cellular and mouse models. PLoS One. 2013;8: e74194.

18. Park C, Shin HJ, Kim GY, et al. Induction of apoptosis by streptochlorin isolated from Streptomyces sp. in human leukemic U937 cells. Toxicol In Vitro. 2008;22:1573-1581.

19. Shin HJ, Jeong HS, Lee HS, et al. Isolation and structure determination of streptochlorin, an antiproliferative agent from a marine-derived Streptomyces sp. 04DH110. J Microbiol Biotechnol. 2007;17:1403-1406.

20. Shin DY, Shin HJ, Kim GY, et al. Streptochlorin isolated from Streptomyces sp. induces apoptosis in human hepatocarcinoma cells through a reactive oxygen species-mediated mitochondrial pathway. J Microbiol Biotechnol. 2008;18:1862-1868.

21. Kwak TW, Kim DH, Chung CW, et al. Synergistic anticancer effects of vorinostat and epigallocatechin-3-gallate against HuCC-T1 human cholangiocarcinoma cells. Evid Based Complement Alternat Med. 2013; 2013:185158.

22. Lim JH. Cholangiocarcinoma: morphologic classification according to growth pattern and imaging findings. AJR Am J Roentgenol. 2003;181: 819-827.

23. Ioka T, Katayama K. The progress of chemotherapy for intrahepatic cholangiocarcinoma. Nihon Shokakibyo Gakkai Zasshi. 2012;109: 1895-1901.

24. Lemarie E, Vecellio L, Hureaux J, et al. Aerosolized gemcitabine in patients with carcinoma of the lung: feasibility and safety study. J Aerosol Med Pulm Drug Deliv. 2011;24:261-270.

25. Oh GS, Kim HJ, Shen A, et al. Cisplatin-induced kidney dysfunction and perspectives on improving treatment strategies. Electrolyte Blood Press. 2014;12:55-65.

26. Kintzel PE. Anticancer drug-induced kidney disorders. Drug Saf. 2001;24:19-38.

27. Jaggi AS, Singh N. Mechanisms in cancer-chemotherapeutic drugsinduced peripheral neuropathy. Toxicology. 2012;291:1-9.

28. Samulitis BK, Pond K, Pond E, et al. Gemcitabine resistant pancreatic cancer cell lines acquire an invasive phenotype with collateral hypersensitivity to histone deacetylase inhibitors. Cancer Biol Ther. 2015;16: 43-51.

29. Lee J, Park SH, Chang HM, et al. Gemcitabine and oxaliplatin with or without erlotinib in advanced biliary-tract cancer: a multicentre, openlabel, randomised, phase 3 study. Lancet Oncol. 2012;13:181-188.

30. Kim DH, Jeong YI, Chung CW, et al. Preclinical evaluation of sorafenibeluting stent for suppression of human cholangiocarcinoma cells. Int J Nanomedicine. 2013;8:1697-1711.

31. Freed-Pastor WA, Prives C. Mutant p53: one name, many proteins. Genes Dev. 2012;26:1268-1286.

32. Shen FZ, Zhang BY, Feng YJ, et al. Current research in perineural invasion of cholangiocarcinoma. J Exp Clin Cancer Res. 2010;29:24.

33. Kuang D, Wang GP. Hilar cholangiocarcinoma: pathology and tumor biology. Front Med China. 2010;4:371-377.

34. Bhuiya MR, Nimura Y, Kamiya J, et al. Clinicopathologic studies on perineural invasion of bile duct carcinoma. Ann Surg. 1992;215: 344-349.

35. Zhou Q, Wang Y, Peng B, et al. The roles of Notch 1 expression in the migration of intrahepatic cholangiocarcinoma. BMC Cancer. 2013; $13: 244$. 


\section{Supplementary materials Estimation of human VEGF using ELISA}

Human vascular endothelial growth factor (VEGF) was detected using a human enzyme-linked immunosorbent assay kit (RayBiotech Inc, Norcross, GA, USA). The assay was run as summarized in the general enzyme-linked immunosorbent assay protocol on 96-well microplates. Optical density was determined using a microplate reader set at $450 \mathrm{~nm}$ (Tecan, Männedorf, Switzerland). The VEGF concentration was read using a standard curve and is given in $\mathrm{pg} / \mathrm{mL}$. The results are represented as the mean \pm standard deviation of experiments performed in triplicate.

\section{Growth inhibition and cytotoxicity of streptochlorin against HEK293 cells}

First, $3 \times 10^{4}$ and $3 \times 10^{5}$ HEK293 cells were seeded in 24-well plates for growth inhibition and cytotoxicity tests, respectively. The cells were incubated overnight in Dulbecco's Modified Eagle's Medium supplemented with $10 \%$ fatal bovine serum and $1 \%$ antibiotics at $5 \% \mathrm{CO}_{2}\left(37^{\circ} \mathrm{C}\right)$. Streptochlorin dissolved in dimethyl sulfoxide was diluted with culture medium for the growth inhibition test and diluted with serum-free Dulbecco's Modified Eagle's Medium for the cytotoxicity test. The HEK293 cells were treated with streptochlorin for 24 hours. The cells were then harvested by trypsinization and resuspended in medium. Cells were stained with Trypan blue for cell counting. Cytotoxicity was evaluated by counting cell numbers using a Countess automated cell counter (Invitrogen, Carlsbad, CA, USA).

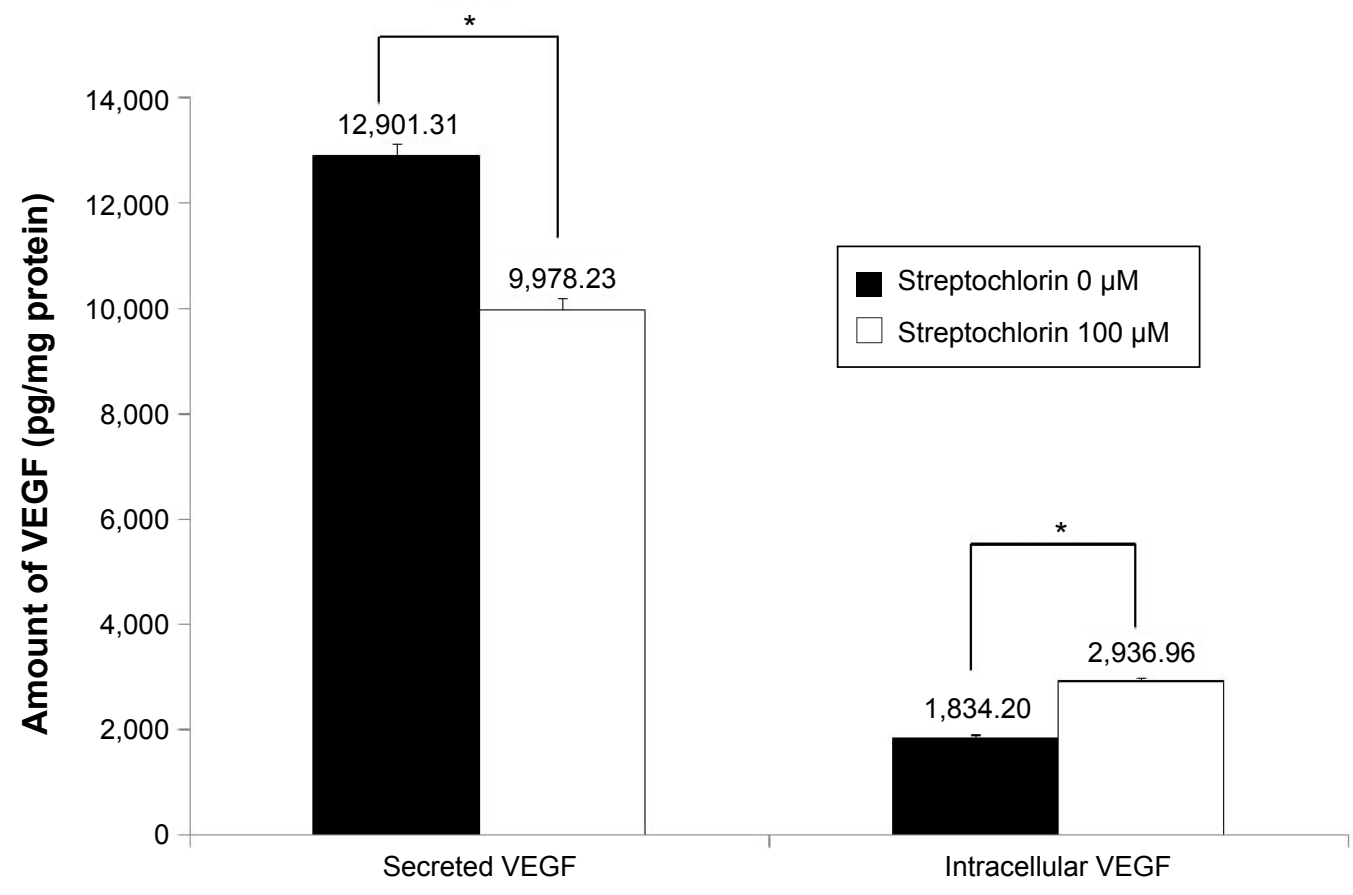

Figure SI Effect of streptochlorin on secreted and intracellular VEGF in SNU478 cells.

Note: $* p<0.001$

Abbreviation: VEGF, vascular endothelial growth factor. 
A
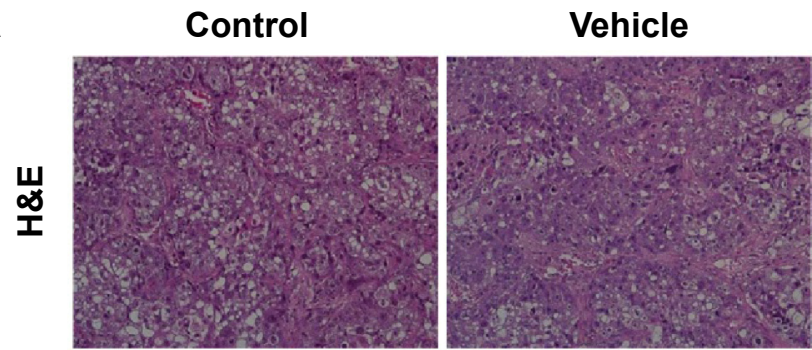

\section{Streptochlorin}
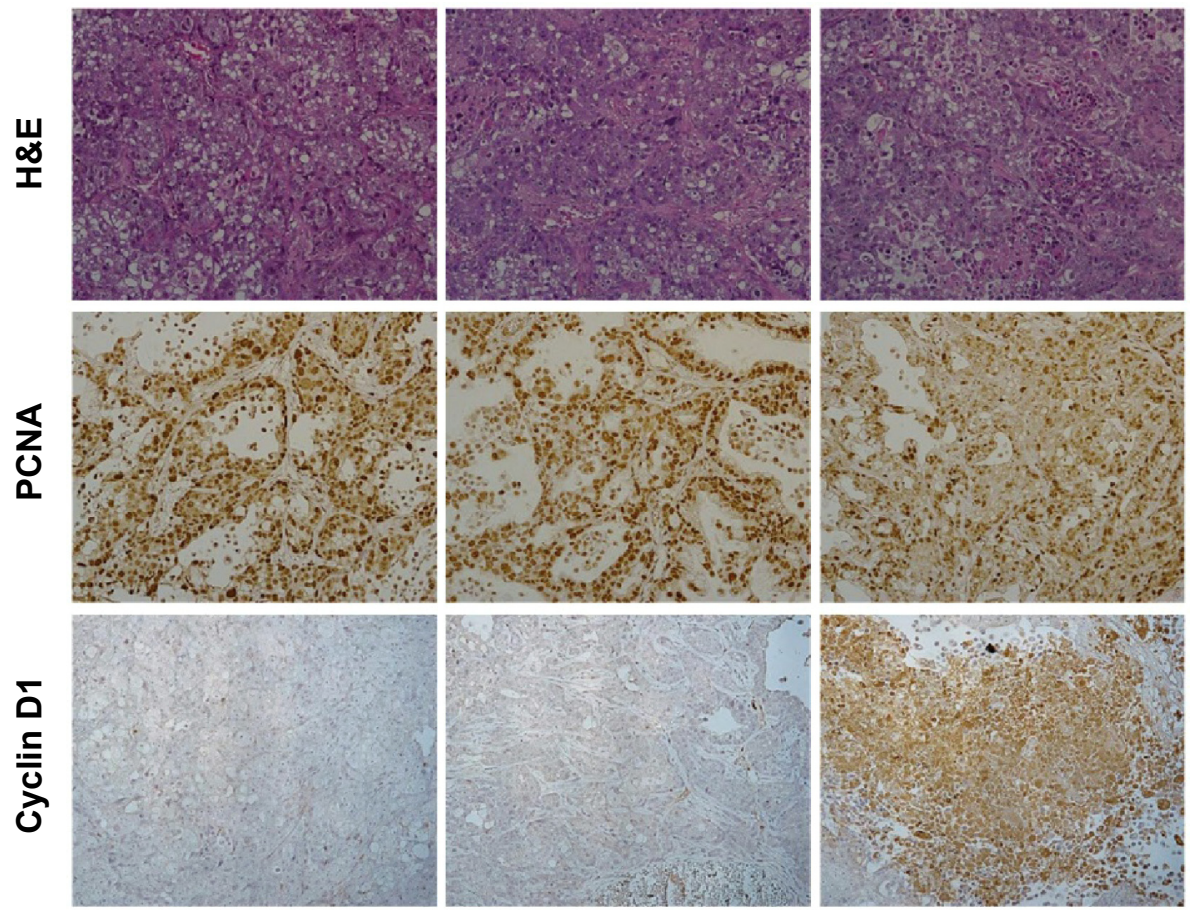

B
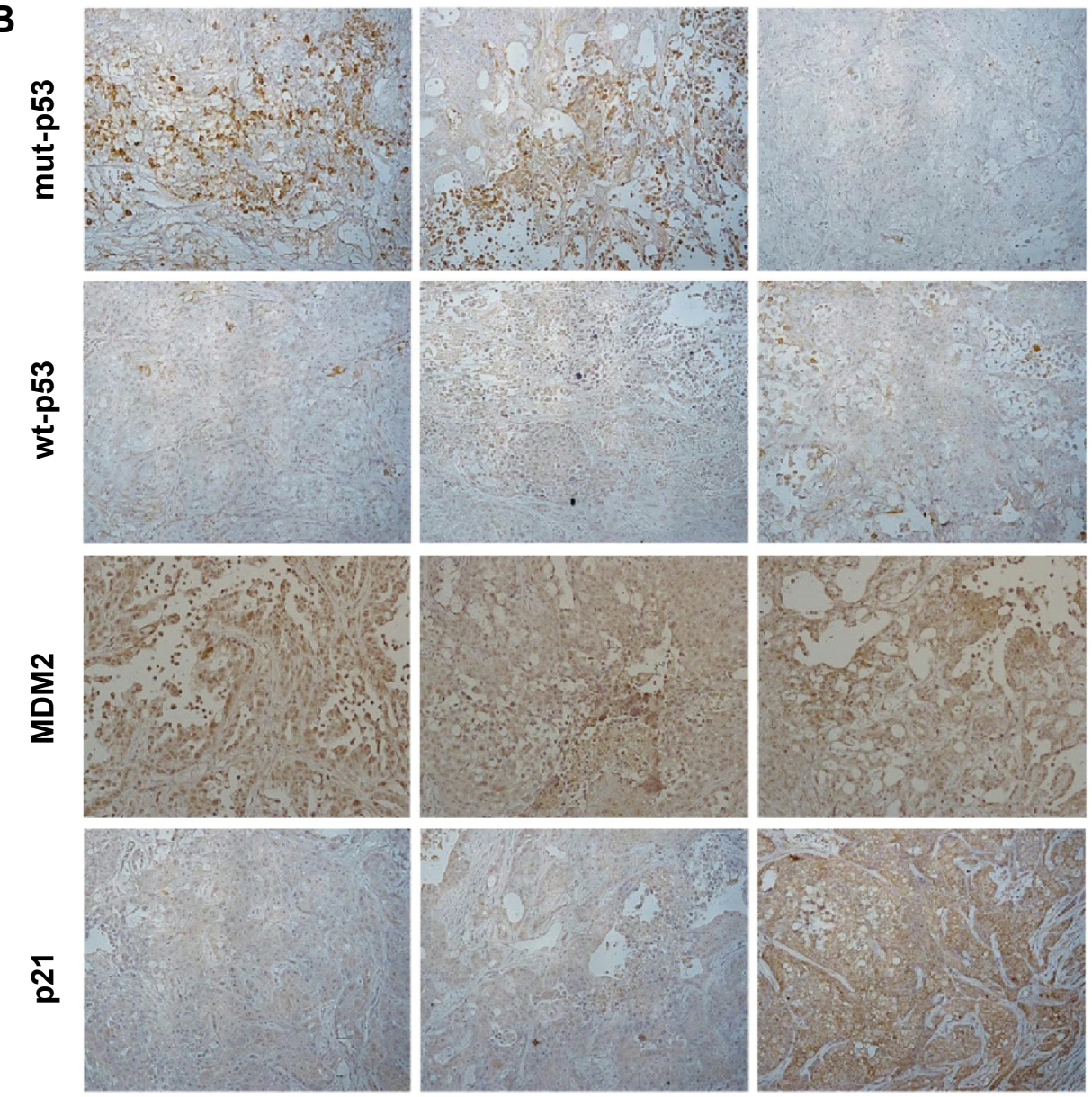

Figure S2 Immunohistochemical staining of solid tumor tissue in an animal tumor model in Figure 5A.

Notes: (A) H\&E staining, PCNA and Cyclin DI, (B) mut-p53, wt-p53, MDM2, and p2I.

Abbreviations: H\&E, hematoxylin and eosin; PCNA, proliferating cell nuclear antigen; mut-p53, mutant p53; wt-p53, wild type p53; MDM2, mouse double minute 2 homolog. 
A
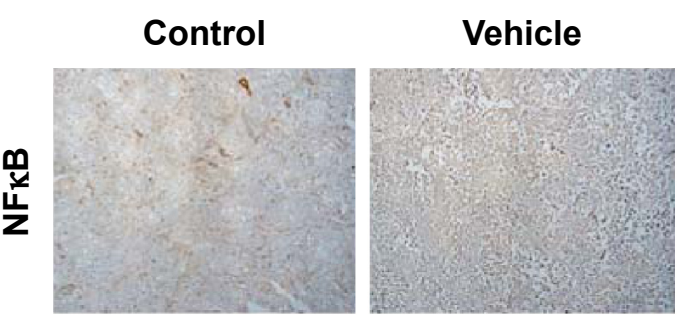

\section{Streptochlorin}
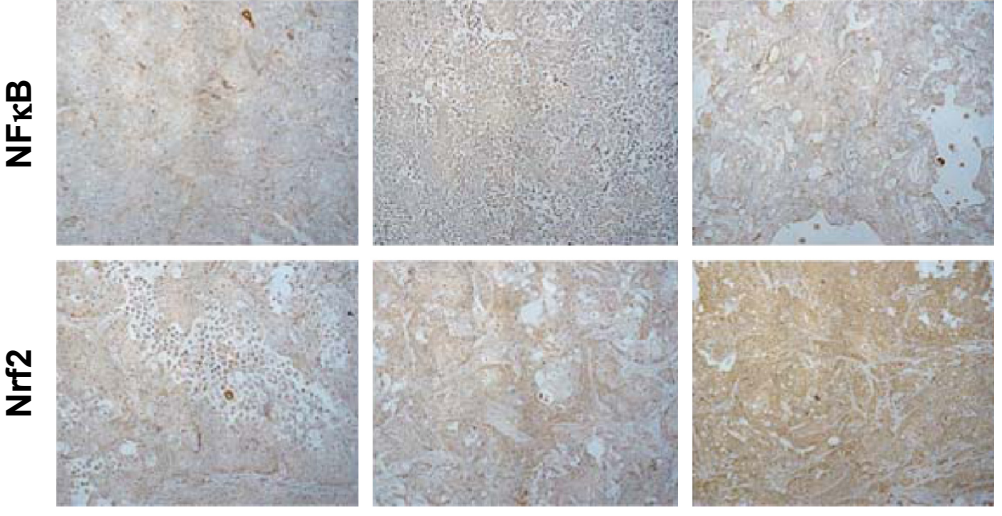

B
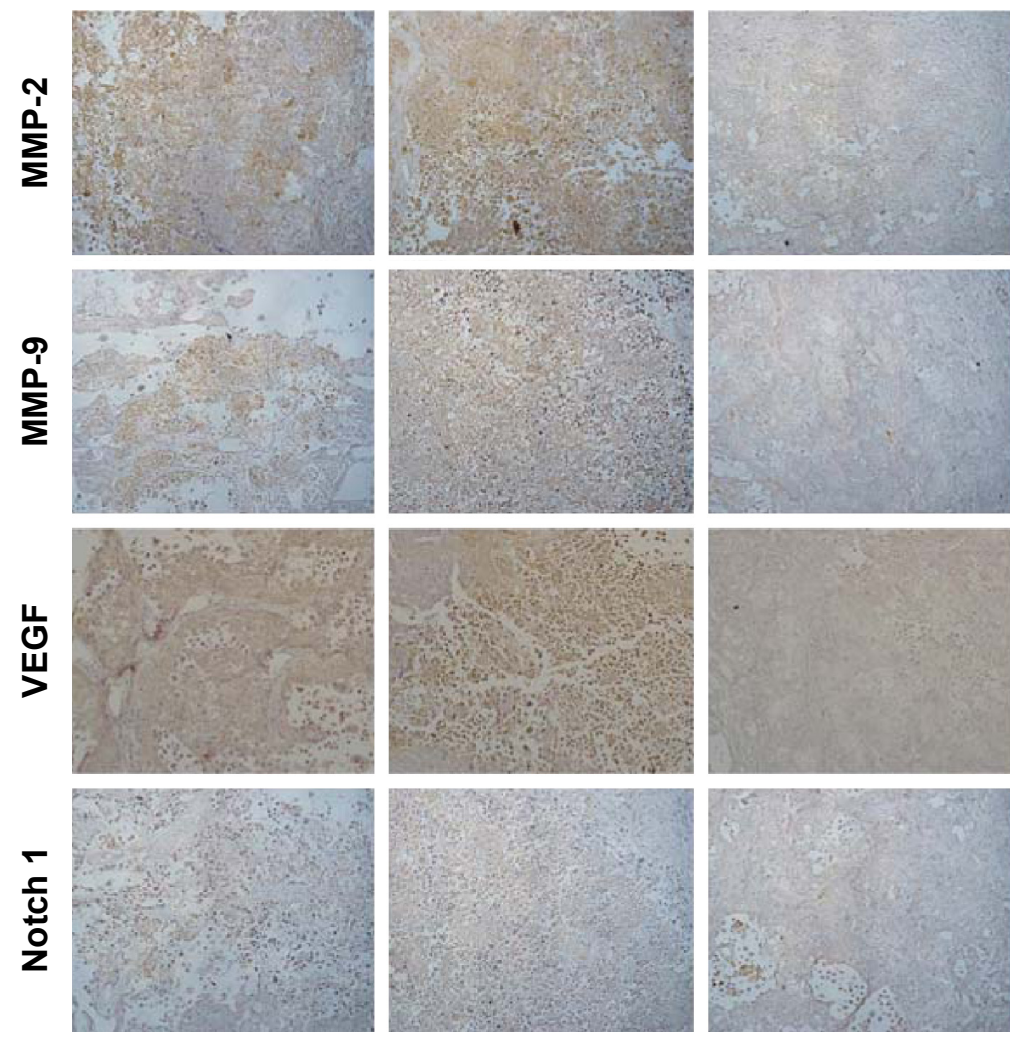

Figure $\mathbf{S} 3 \mathbf{I m m u n o h i s t o c h e m i c a l ~ s t a i n i n g ~ o f ~ s o l i d ~ t u m o r ~ o f ~ a n i m a l ~ t u m o r ~ m o d e l ~ i n ~ F i g u r e ~} 5 \mathrm{~A}$.

Notes: (A) NFKB, Nrf2, (B) MMP-2, MMP-9, Notch I, VEGF.

Abbreviations: MMP, matrix metalloproteinase; NFKB, nuclear factor kappa B; VEGF, vascular endothelial growth factor. 


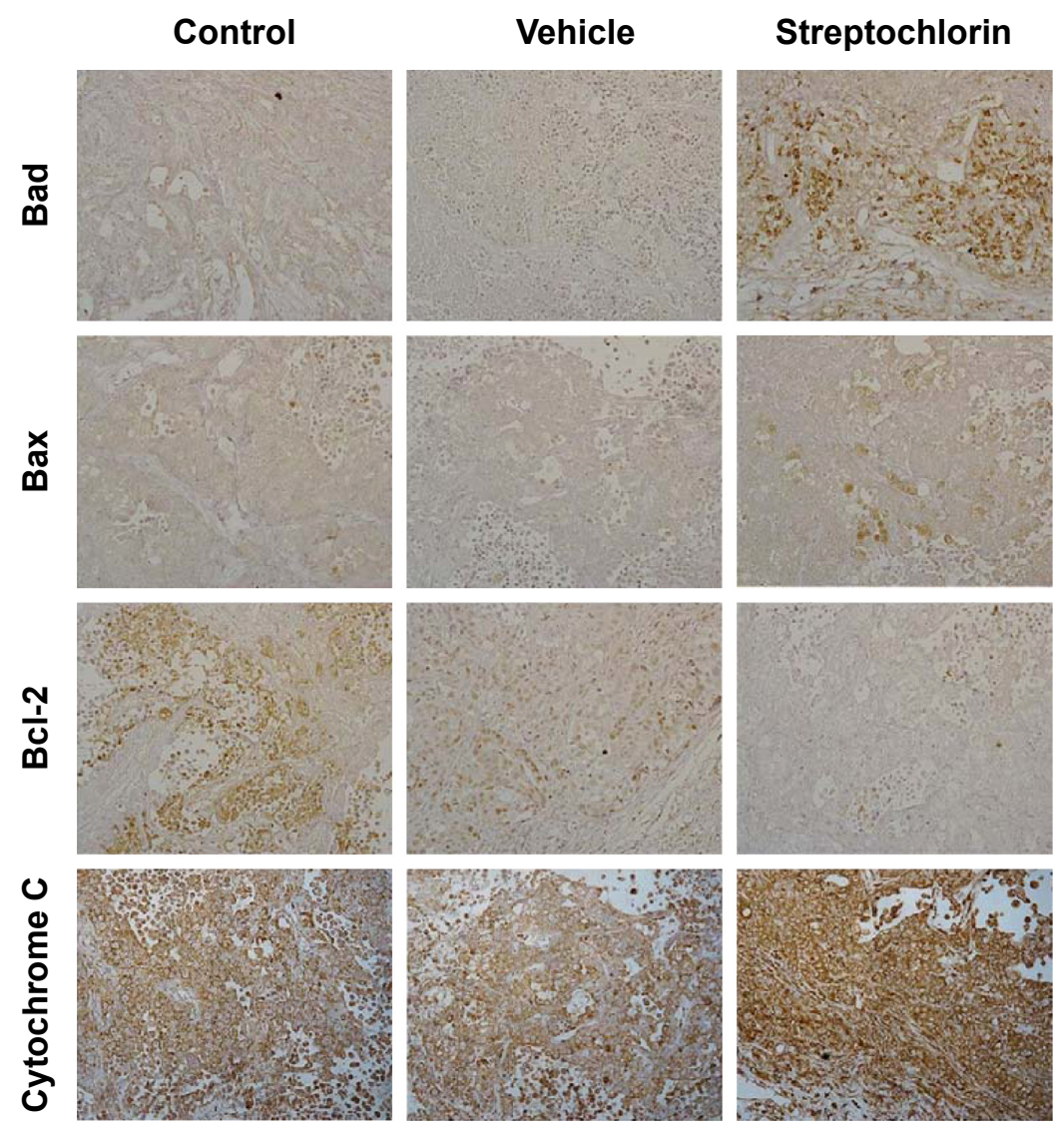

Figure S4 Immunohistochemical staining of solid tumor tissue in an animal tumor model in Figure 5A. Bad, Bax, Bcl-2, and cytochrome C.
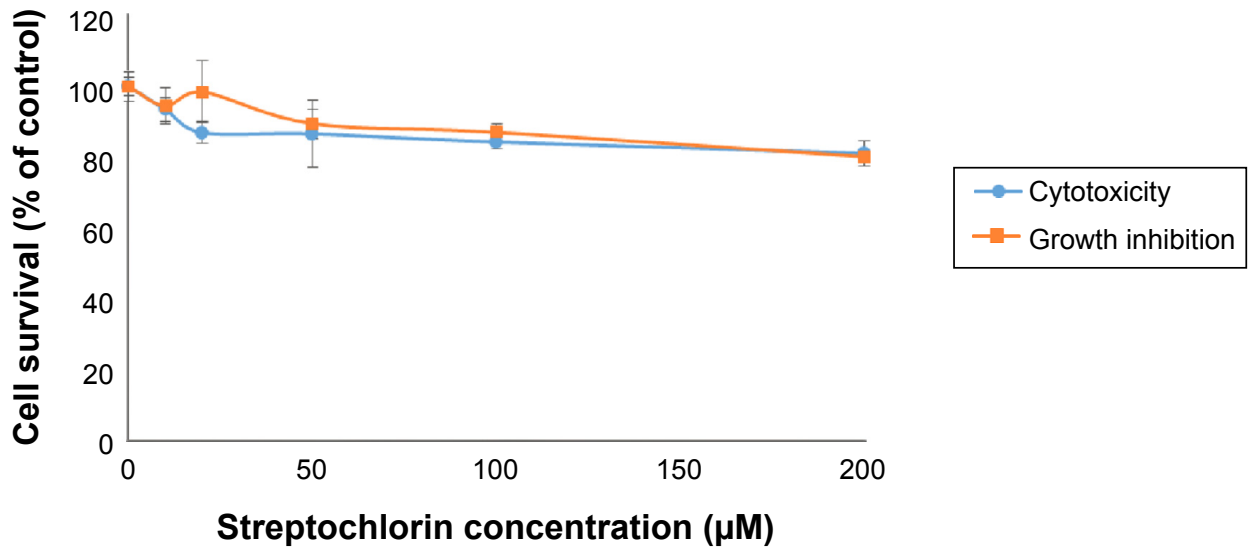

Figure S5 Cytotoxicity of streptochlorin to HEK293 cells.

Drug Design, Development and Therapy

\section{Publish your work in this journal}

Drug Design, Development and Therapy is an international, peerreviewed open-access journal that spans the spectrum of drug design and development through to clinical applications. Clinical outcomes, patient safety, and programs for the development and effective, safe, and sustained use of medicines are a feature of the journal, which

\section{Dovepress}

has also been accepted for indexing on PubMed Central. The manuscript management system is completely online and includes a very quick and fair peer-review system, which is all easy to use. Visit http://www.dovepress.com/testimonials.php to read real quotes from published authors.

Submit your manuscript here: http://www.dovepress.com/drug-design-development-and-therapy-journal 